\title{
Path Research on Quality Management of Organization of the Youth League in Colleges and Universities
}

\author{
Huang Lirong \\ School of Economics and Management, Xiamen University of Technology, Xiamen, China
}

Keywords: colleges and universities; management of League member; strengthen League self-discipline; quality control

\begin{abstract}
To promote the strengthening of League self-discipline in new trend shall become the new normal of the construction of Youth League, to establish the concept of total quality management and continuously improve the management quality of student League member in colleges and universities. This paper, explores quality management path of Youth League in colleges and universities from establishing environment, defining task, setting performance objective, making a plan, implementing with tools and methods, evaluating achievements and reviewing and correction, so as to provide basic thinking and methods for management of student League member in colleges and universities, and enriches the theoretical system of management quality model of League members in colleges and universities.
\end{abstract}

The Third Plenary Session of the 17th Central Committee of the Youth League clearly stated that it is necessary to adhere to strengthen Party self-discipline and to temper the League style. "This is not only the inherent meaning of implementing the comprehensive strengthening of Party self-discipline, but also the inevitable requirement of the Communist Youth League to consolidate and expand the youth mass base of Party's ruling and to keep the vitality of the Communist Youth League forever." ${ }^{[1]}$ At present, there are a certain number of weak grassroots League organizations in colleges and universities, and the quality of certain League branches and members needs to be improved. The society and the times put forward higher requirements for the grassroots League construction in colleges and universities. Under the background of strengthening League self-discipline, grassroots League construction in colleges and universities shall take improving the quality if League organizations and members as main goal, accurately design procedures of quality management, elaborately plan education, management and service activities and content, continuously improve work quality, greatly promote the strengthening of League self-discipline and form the new normal of League construction, which is the important guarantee for the League to eliminate the "institutionalization, administerization, noblization and entertainment", strengthen the "political nature, advancement and mass participation”, and establish four-dimensional work pattern of "uniting the youth, serving the overall interests, serving as a bridge and strengthening League self-discipline” to vitalize the League organizations.

\section{To establish the concept of total quality management and continuously improve the management quality of student League member in colleges and universities}

TQM (Total Quality Management), is a management approach centering on quality management and based on full participation, to achieve customer satisfaction and the interests of the organization's owners, employees, suppliers, partners or society, so as to achieve long-term success ${ }^{[3]}$.

The establishment of total quality management concept in grassroots organizations in colleges and universities is conducive to improving the quality of League construction, improving the efficiency of the Communist Youth League and shortening the work cycle; improving the quality of personnel training, promoting the progress and development of the times; and better meeting the demand of market and society. The application of total quality management concept in the League organizations of colleges and universities, promotes the whole process of daily education 
management of League members, promotes the disposal of unqualified members, promotes to rectify and enhance the combat effectiveness of the weak grassroots League organizations, and promotes to guide each youth member to improve the employment competence, promotes to enhance the ability of League organizations to organize scientific research and serve industry economic development, and promotes to adapt to market demand, contribute to society and inherit culture, etc.

The implementation of total quality management in colleges and universities in the whole process shows its comprehensiveness; relying on all the Communist Youth League and the majority of youth League members reflects the full participation; the process of League construction focuses on high preventability; the Youth League branches meeting social services and demand of employer units shows the serviceability; the League construction is more consciously using modern science and technology and advanced scientific management methods to achieve scientification, showing scientificity; and all these characteristics are the era requirements and development trend of the League construction in colleges and universities in the new era.

\section{To explore quality management system of League organizations in colleges and universities under the strengthening of League self-discipline}

In League construction in colleges and universities, based on sticking to League member management basic principle of strengthening League self-discipline, quality management guarantee of League members shall takes serving the growth of youth League members as the purpose and give full play to the self-development awareness of mass youth League members.

\subsection{The quality management goal of League organizations in colleges and universities}

The goal of enterprises adhering to total quality management in overall activities is to develop high-quality products that customers are willing to purchase. Based on the perspective of the cultivation process of colleges and universities, the majority of youth League members can be regarded as the "products" of colleges and universities. From the perspective of providing excellent products and providing quality services, the quality objectives of colleges and universities is to provide more and better graduates for the society, and provide higher and better volunteer services for local level and industry.

The League organizations in colleges and universities must unremittingly conduct the "Youth Marxism Project" of the Central Committee of the Communist Youth League, arm the youth with the latest achievements of Marxism in China, and continuously improve the ideological and political quality, policy theory level, innovative capacity, practical ability and organizational coordination capabilities of student members in an effective way. Total quality management must cover issues from two aspects.

(1) To focus on the improvement in the quality of "product". League organizations can guide student League members to learn and master the theoretical innovation achievements of the Party, understand the national conditions, and understand the society; organize student League members to go deep into enterprises, communities and rural areas, carry out grassroots practice activities such as visits and inspection, social investigations, production work, and experience of folk customs, enhance the feelings of the working masses, increase the in-depth experience of social conditions and national conditions, and improve their social adaptability.

(2) To focus on the improvement in the capability of "service". League organizations can organize youth student members to participate in youth volunteer service, and enhance their social responsibility by participating in policy propaganda, "three support public policies and one assistance", art performances and other volunteer activities in rural areas, communities and campuses, organize some high-quality volunteer services, and meet local economic development and industrial needs, to effectively improve the service ability of student League members and improve their overall quality. 


\subsection{The quality management methods of League organizations in colleges and universities}

The whole process of total quality management is the process of formulating and organizing the quality plan. It is necessary to collect a large amount of data and comprehensively apply various management techniques and methods, and follow the PDCA cycle to run the process continuously. The PDCA cycle, also known as the Deming Cycle, is the basic method for the operation of total quality management system. The basic idea is to emphasize the continuous improvement of the quality system in the process of quality management practice ${ }^{[4]}$. According to the PDCA cycle, the total quality management of League organizations in colleges and universities can be divided into four stages.

\subsubsection{The first stage of $P$ (Plan)}

To determine the work objectives and work plans of League organziations, determine the work system and methods to achieve the objectives, pre-judge the work, and make plans for possible accidents and hidden dangers. According to the natural year, the guidance and implementation points of the Communist Youth League work are generally formulated at the beginning of the year, including the work ideas, work directions and work objectives for the whole year. The total quality management tools such as the "fishbone chart" are applied to make specific arrangements to the month and even the week. For youth volunteer activities, major festival celebrations, "May 4th" promotion, and youth innovation activities to be promoted in the year, it is necessary to plan and implement them in advance and implement them by the department and specific personnel.

\subsubsection{The second stage of $D$ (Do)}

League organizations shall develop quality solutions to be implemented powerfully according to the plan. Quality assurance is provided for the implementation process through education and training. The normalized theme League day activities not only enhance the theoretical level of youth League members, but also enhance their ability to serve localities and industries.

\subsubsection{The third stage of $\mathrm{C}$ (Check)}

To focus on the quality objectives of League organizations, take whether to improve the quality of student League members and whether to enhance the ability to serve locality and industry as the standard to check whether the implementation stage is carried out according to the objective setting. For the dissemination effect of the League construction activities, League organizations can take the feedback of the volunteer service audience, employer units and the society as the basis for the checking, and prepare for the correction of the deviation at any time.

\subsubsection{The fourth stage of $A$ (Act)}

League organizations adopt adjustment measures for the inspection results, and respond urgently to the temporary emergencies, through in-depth analysis, find the reasons that affect the implementation effect and quality, and propose optimization plans for the projects and links that need improvement. In the constant correction and circulation, the standardized implementation path of the League construction work shall be found to prevent the sudden occurrence of bad conditions and achieve the management effect of complete quality control.

\subsection{The quality management paths of League organizations in colleges and universities}

According to the "whole process" requirements of total quality management, the process control is taken as an example to explore the quality management path of League organizations in colleges and universities, shown in Figure 1.

\subsubsection{To establish the environment}

The massive increase of information and the extreme diversification of information transmission channels have weakened the value guidance and public opinion control ability of mainstream ideology, and League organizations in colleges and universities face new problems and challenges in the new era. Due to the trends towards the profit of the market economy, people pay more 
attention to the realization of personal interests, which has greatly collided and impacted the Marxist value system. These questions allow us to examine the necessity and urgency of establishing a total quality management system from the leadership level. When League organizations establish the vision of total quality management from the leadership level of the higher-level League organization and the school Party committee, and make a long-term commitment to the League construction from the strengthening of League self-discipline, lead the youth League members to participate in the implementation of the strengthening League self-discipline, which have initially laid the foundation for the total quality management and the grassroots League organization culture and League construction work environment.

In TQM, keep the full participation of all League cadres and youth League members, and consistent personal goals and organizational goals in the quality management process, the quality loss is relatively small, and the quality process shows less input, more output and maximize benefits. Each individual is easy to identify with the organization to stimulate the love for the organization. League organizations have harmonious and intimate atmosphere, and the conflicts and conflicts between them tend to weaken, which is conducive to the smooth and efficient work of League organizations.

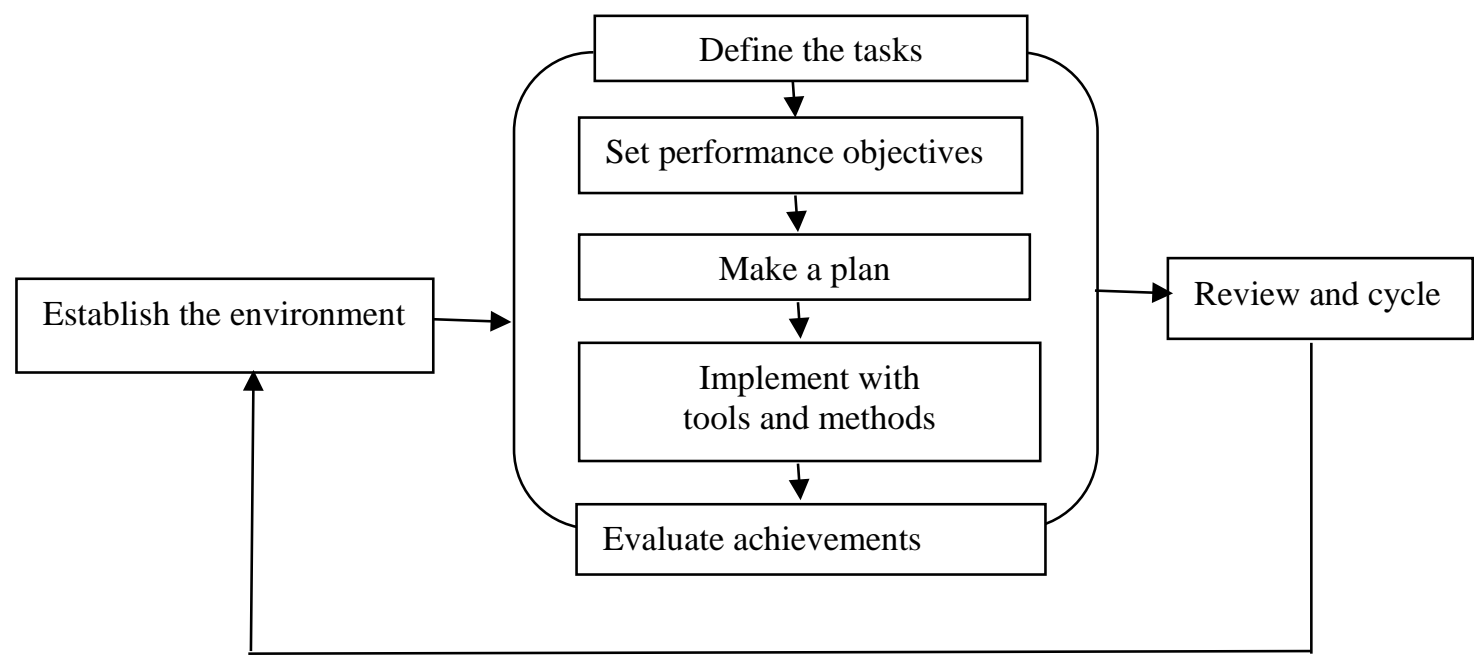

Figure 1 The quality management paths of League organizations in colleges and universities with process control

\subsubsection{To define the tasks}

TQM focuses on creating customer value and adheres to the quality goal of "Customer First". Employees are required to focus on how to provide customers with products and services that meet their needs and expectations. Based on the TQM concept, League organizations focus on how to provide student League members for the society who can meet the needs and expectations of the society. Each member of the organization branch must understand their social responsibility and work mission. The League cadres are committed to the task of leading, educating and managing League members. Students are dedicated to the tasks of profession promotion and social service practice, and work together for this purpose. League organizations in colleges and universities center on the central task, effectively play the role of the fighting bastion of the Communist Youth League and the vanguard and exemplary role of outstanding Communist Youth League members, comprehensively strengthen the thinking, organization, style, discipline and system construction of the Communist Youth League, and provide strong idea, political and organizational guarantees for promoting the overall quality development of colleges and universities. The quality of youth League members is an important content and indicator to measure whether the organization is centered on central tasks, whether it meets social needs, whether it wins social satisfaction, and whether to create product value. Therefore, establish task indicators that improve the quality of League cadres and student League members should be the consensus of the League construction in colleges and universities. 


\subsubsection{To set performance objectives}

The organization main body of League construction work system in colleges and universities includes the school League committee, (the secondary school sub-committee), and the class League branch (three levels). Setting performance objectives should be set by the school League branch (high-level management) to reflect key processes that are critical to organizational development or strategic choices that meet social expectations. For secondary school sub-committee as the middle management level and class League branch as an operation manager, it is necessary to set a double standard of function and process improvement in order to achieve the strategic goal set by the high-level management. In other words, the secondary school sub-committee is not only the executor of the performance objective of the higher-level school League committee, but also the designer of the performance objective of the lower-level class League branch.

Practice has shown that quality management failure has a very important reason, that is, the objective is not well designed or the objective design is wrong. Unrealistic objectives may have significant benefits in the short term, but in the long run often undermine final performance. For example, a certain so-called appropriate price is set by a certain department in an enterprise, which although improves the efficiency of the procurement department in a short time, whereas, it is at the expense of the quality standard of the production department. Therefore, in the TQM system, the performance objectives of the secondary school sub-committee, from the process goal to the setting of the result goal, should pay attention to make use of relevant means, closely follow the overall goal of continuous improvement of quality, to avoid the ever-changing problems, and in particular, pay attention to the basic goal of "Customer First" and the monitoring process of continuous improvement of quality. The secondary school sub-committees and the class League branches, should work together to improve quality under the guidance of the performance targets set by the school League committee.

\subsubsection{To make a plan}

The performance improvement goal of the League construction in colleges and universities should cover the highest management level to the implementation level. The secondary school sub-committee can achieve these goals through the establishment of the Communist Youth League working group and organization team activities through organization, propaganda, practice and public relations department. According to the function setting of total quality management, the working group can be roughly divided into steering group, improvement group and problem-solving group. The steering group can be composed of the Secretary of the secondary school sub-committee and the office members of the Youth League committee. Guided by the TQM concept, the short-term goal, long-term goal and identification key process of the League branch are set. The improvement team may be composed of relevant personnel such as the organization department of the secondary school sub-committee and the propaganda department, and improvement goals and action plans are set. The problem-solving team can be composed of the League branch Secretary and student League cadres, with structural approach to implement the improvement plan.

The League work group of the secondary school sub-committee in colleges and universities pays attention to the quality management of the basic League construction, the quality management of the process and the links, grasps the key processes of the theme League day, volunteer service and social practice of the Party and League branches, formulates the improvement plan of team activities such as study, inspection and practice, takes strict discipline, strict education and management of members, and strengthens the supervision. At the same time, it builds carriers, clears channels, improves evaluation mechanism, forms style and corrects discipline, consolidates the achievements of the League work style, and builds grassroots League construction brand.

\subsubsection{To implement with quality tools and scientific methods}

In the total quality management activities of the construction of the Communist Youth League in colleges and universities, there are several practical and scientific tools such as checklist, arrangement diagram, causal map, layering, histogram, control chart and scatter chart. The leader of 
the League work group of the secondary school sub-committee should be able to use these tools skillfully, collect data systematically, accumulate information, confirm facts, and roughly sort and analyze the data, confirming whether it exists or not, whether the work is done, and whether the League construction work is complete, using the checklist to analyze the reasons that affect the quality of student League members, the fast and effective "fishbone chart" (cause and effect diagram) to analyze causes one by one, find countermeasures, and start the improvement.

\subsubsection{To evaluate achievements}

To evaluate process quality is an important part of total quality management. There is a famous saying in Lean Six Sigma management, "There is no management without evaluation, and there is no improvement without management." The evaluation of the results of the League construction of colleges and universities, shall be conducted based on the project plan of TQM model, behavior change and quality loss, in the quality of League members of the secondary school sub-committee, the implementation of the work process, communication, employment rate and quality of employment of college students, the employer's evaluation of the school and students, the professional satisfaction of students, etc., and the performance measurement tools are used to evaluate student League members and the organizations of the secondary school sub-committees and class League branches. TQM adheres to accurate measures, such as the evaluation of results based on the index system of the work list of League construction of branch League committees.

\subsubsection{To review, correct and cycle}

Communication between organizations shall be open and smooth. If there are many gaps between departments in the organization, there are more closed loops in the organization and circulation procedures, and the organizational system and hierarchy are more complicated, so quality management training will be difficult to achieve substantial results. Based on the TQM concept, through the correction cycle to open up the organization's links, make it open and smooth. The Party committees and League committees of colleges and universities adhere to the strict management of the League cadres, so that the cadres are alerted with the bottom line and the awe. The secondary school sub-committee focuses on strengthening the team building of each class League branch, relying on the theme League day, social practice, volunteer service and other carriers, and strengthens the discipline and rule education of student League members, strict in the attendance of League member meetings and activities, and collection and management of League membership dues. League organizations must persevere in the process of continuous improvement. Measure, analyze, and control the processes that have been improved, review, correct, and cycle, so that League cadres and student members understand that TQM is not just a plan, but a new behavioral model for every member, to improve the quality of the work continuously.

The system is a circulation from the "establishment of the environment" as the starting point, from "defining the task" to "evaluating the results", to "reviewing, correcting and cycling", and then to the starting point. As shown in Figure 1, the second round of cycle is the continuous improvement of the first round of circulation. Through continuous circulation and improvement, the total quality management of League organizations in colleges and universities is realized.

\section{Acknowledgements}

This paper is the key project of research on Communist Youth League in national schools in 2017 (Project No. 2017ZD095), the project of Fujian young and middle-aged teachers education scientific and research in 2017 (School Party construction and ideology and politics project), (Project No. JZ170268), scientific and research project result of ideological and political work for students of Xiamen University of Technology in 2016, (Project No. SZ2016C08).

\section{References}

[1] Yu Yiqun. Playing well the Symphony of the Times on Strengthening the Discipline and Reform 
of the Communist Youth League [J]. Beijing Youth Research, 2017 (4): 46-47.

[2] On the Promotion of Strengthening League Self-discipline in New Trend. January 23, 2017. CYLF (2017) No. 3. Passed in The Sixth Plenary session of $17^{\text {th }}$ Central Committee of China Communist Youth League.

[3] Shi Qiang, Zhu Shiyou. Manual of Total Quality Management [M]. Beijing: China Electric Power Press, 2013: 62-63.

[4] Su Qin. Modern Quality Management [M]. Beijing: Tsinghua University Press, 2013:8-9. 